\title{
PENGARUH ANGGARAN PARTISIPATIF TERHADAP KINERJA PADA LEMBAGA KEUANGAN SYARIAH YANG DI MEDIASI KEADILAN PERSEPSIAN DAN KOMITMEN
}

\author{
Selamet Eko Budi Santoso ${ }^{1}$,Wage $^{2}$ \\ ${ }^{1}$ Universitas Muhammadiyah Purwokerto \\ ${ }^{2}$ Universitas Muhammadiyah Malang
}

\begin{abstract}
ABSTRAK
Penelitian ini menguji apakah penganggaran partisipatif mempengaruhi kinerja, dan apakah pengaruh tersebut dimediasi oleh keadilan persepsian dan komitmen terhadap tujuan. Penelitian ini dilakukan pada Lembaga Keuangan Syariah, yaitu Baitulmal Wattamwil (BMT), di Kabupaten Banyumas.

Penelitian ini menggunakan sampel manajer dan kepala bagian keuangan lembaga keuangan mikro syariah. Data dikumpulkan dengan cara pengisian kuesioner. Metode statistik yang digunakan untuk menguji masing-masing hipotesis adalah Structural Equation Modelling Partial Least Square (SEM PLS) menggunakan WARP PLS.

Penelitian ini menemukan bahwa: (1) penganggaran partisipatif positif mempengaruhi kinerja manajerial; (2) pengaruh tersebut dimediasi sebagian oleh keadilan prosedural dan komitmen terhadap tujuan.
\end{abstract}

Kata kunci: Anggaran Partisipatif, keadilan distributive, keadilan persepsian, komitmen kinerja, BMT. 


\begin{abstract}
THE EFFECT OF PARTICIPATORY BUDGETS ON PERFORMANCE IN SHARIA FINANCIAL INSTITUTIONS IN THE MEDIATION OF JUSTICE OF EXCEPTION AND COMMITMENT
\end{abstract}

This study examines whether participatory budgeting affects performance, and whether it is mediated by perceptions of justice and commitment to goals. This research was conducted at Sharia Financial Institution, Baitulmal Wattamwil (BMT), in Banyumas Regency.

This study used a sample manager and head of finance department of sharia micro finance institutions. Data collected by filling out questionnaires. The statistical method used to test each hypothesis is Structural Equation Modeling Partial Least Square (SEM PLS) using WARP PLS.

The study found that: (1) participatory budgeting positively affects managerial performance; (2) the effect is mediated in part by procedural justice and commitment to goals.

Keywords: Participatory budgeting, distributive justice, perceptions of justice, performance commitment, BMT. 


\section{PENDAHULUAN}

Kehadiran koperasi syariah atau yang lebih dikenal baitulmal wattamwil (BMT) sangat tepat untuk merespon persoalan pendanaan yang dihadapi masyarakat dan pelaku UKM. Masyarakat yang selama ini belum tersentuh oleh lembaga keuangan bisa memanfaatkan BMT. Sebab BMT merupakan lembaga keuangan mikro syariah berbasis kerakyatan yang langsung bersinggungan dengan masyarakat; tidak hanya di perkampungan dan desa-desa, tetapi masyarakat perkotaan yang tidak tersentuh lembaga keuangan besar. Sehingga keberadaannya sangat membantu masyarakat terutama rakyat kecil dalam memperoleh dana. Lahirnya BMT yang semula hanya bermodalkan semangat dan keprihatinan, seiring dengan mulai berkembangkanya institusi mulai menerapkan manajemen modern yang mengedepankan aspek profesonalitas. Tidak heran jika keberadaan BMT mulai tumbuh dan berkembang secara signifikan. Peran BMT dalam memberikan kontribusi kepada bergeraknya roda ekonomi kecil sangat riil. Sudah banyak BMT yang telah berkontribusi bagi pemberdayaan masyarakat dan terus mengalami pertumbuhan signifikan.

Perkembangan BMT selama kurun waktu 2015 telah mengalami perkembangan yang cukup signifikan.Dengan asset mencapai 4 trilyun lebih, menunjukkan kalau lembaga keuangan mikro syariah ini mampu bersaing dengan lembaga-lembaga keuangan lain secara professional.Bahkan beberapa BMT menunjukkan kinerja yang sangat bagus, misalnya BMT Bina Ummat Sejahtera Lasem-Rembang, BMT Tamzis wonosobo yang assetnya hampir 1 trilyun (Republika, 2015).

Kinerja perusahaan yang meningkat pesat ini menunjukkan bagaimana perusahaan dikelola dengan sangat profesional. Kinerja manajerial dalam mengembangkan institusinya mungkin saja dipengaruhi oleh beberapa faktor. Diantaranya adalah keterlibatan manajemen dalam menyusun atau menentukan anggaran perusahaan.

Beberapa penelitian tentang hubungan antara partisipasi pada proses penganggaran (participative budgeting) dan kinerja (performance) cukupkompleks dan tidak selalu konsisten (Lau dan Tan 2006 dalam Lau dan Moser 2008; Nouri dan Parker 1998) dalam Hasnisari (2014). Beberapa peneliti menemukan hubungan antara partisipasi pada penganggaran adalah positif antara kedua variabel tersebut (Argyris 1952 dalam Nouri dan Parker 1998; Becker dan Green 1962) dalam Hasnisari (2014).

Menurut Shields dan Shields (1998) dalam Mulyasari (2005), hubungan antara penganggaran partisipatif dan kinerja manajer dipengaruhi oleh faktor lain 


\section{Islãmadîna \\ JURNAL PEMIKIRAN ISLAM}

sebagai variabel intervening. Faktor tersebut bersifat spesifik dan bukan semata-mata disebabkan oleh keterlibatan manajer subordinat itu sendiri dalam proses penganggaran.

Penelitian yang dilakukan olehMagner dan Welker (1994) serta Magner dan Johnson (1995) dalam Linquist (1995) dan Hasnuari (2014) mengemukakan bahwa keadilan persepsian (perceivedfairness) adalah salah satu variabel penting yangdapat memediasi hubungan partisipasi pada penganggaran terhadap kinerja. Partisipasi dalam organisasi memungkinkan timbulnya rasa diperlakukan secara adil sehingga dapat mendorong individu untuk meningkatkan kinerja.

Penelitian sebelumnya yang menunjukkan keadilan persepsian dan komitmen terhadap tujuan merupakan dua variabel yang sangat penting yang menghubungkan partisipasi terhadap penganggaran dan kinerja.Wentzel (2002) melakukan penelitian hubungan antara partisipasi penganggaran dan kinerja dengan variabel pemediasi keadilan persepsian dan komitmen terhadap tujuan.Penelitian Wentzel (2002) membuktikan bahwa keadilan persepsian memediasi hubungan antara partisipasi pada penganggaran dan komitmen terhadap tujuan, sedangkan komitmen terhadap tujuan memediasi hubungan antara keadilan persepsian dan kinerja (Hasniasari, 2014).

Hasniasari (2014) melakukan penelitian penganggaran partisipastif mempengaruhi kinerja pada lembaga Hukum di Indonesia menemukan bahwa terdapat hubungan positif bahwa keterlibatan dalam proses penganggaran akan meningkatkan kinerja organisasional. Hal ini menunjukkan pentingnya keterlibatan karyawan dalam proses penganggaran perusahaan.

Secara spesifik penelitian ini akan menguji apakah partisipasi pada penganggaran mempengaruhi kinerja, dan apakah keadilan persepsian dan komitmen terhadap tujuan anggaran memediasi hubungan antara partisipasi pada penganggaran dan kinerja di lembaga keuangan syariah (BMT) di kabupaten Banyumas.

\section{LANDASAN TEORI}

\section{Partisipasi pada Penganggaran dan Kinerja}

Penganggaran merupakan salah satu proses perencanaan manajerial yang sangat penting. Karena penganggaran merupakan indikator kegiatan perusahaan beserta capaian-capaian yang diinginkan. Salah satu tipe proses penganggaran adalah penganggaran partisipatif, yakni melibatkan semua tingkat manajemen. Keterlibatan manajer dalam penganggaran mempunyai hubungan yang positif 
dengan kinerja manajer. Yakni, semakin besar keterlibatan manajer dalam penyusunan anggaran, semakin tinggi kinerjanya Mulyasari : 2005). Partisipasi pada proses penganggaran merupakan kegiatan penyusunan anggaran dengan melibatkan pihak-pihak terkait dalam organisasi, agar hasil dari pengambilan keputusan tersebut dapat sesuai dengan kebutuhan organisasi. Partisipasi karyawan dalam proses menentukan anggaran memberikan kesempatan pada atasan untuk meningkatkan akses pada informasi lokal (localinformation) yang terjadi pada setiap bagian di dalam organisasi, sehingga dapat mereduksi informasi yang asimetris.

Kinerja manajerial menunjukkan kemampuan individu dalam mengelola organisasi perusahaan, yang ditunjukkan dengan capaian-capaian tertentu yang ditetapkan perusahaan. Kinerja Manajerial menurut Mahoney et.al (1963) adalah kinerja para individu dalam kegiatan manajerial. Kinerja individu meliputi delapan dimensi yaitu perencanaan, investigasi, pengkoordinasian, evaluasi, pengawasan, supervisi, pengaturan staf, dan perwakilan. Penelitian yang dilakukan olehPollitt (1999) dalam Smith dan Goddard (2002) menggambarkan kinerja manajerial sebagai aturan dari lima proses yang ada pada organisasi, yaitu: (1) penentuan tujuan, (2) penugasan kewajiban, (3) pengukuran kinerja, (4) umpan balik informasi untuk pengambilan keputusan, dan (5) akuntabilitas(dalam Hasniasari: 2014). Penelitian lain yang dilakukan oleh Hasmawati dan Laela (2011), Hafiz (2007), Nurcahyani (2010), dan Adrianto (2008) dalam Aji et.al(2014), telah memberikan bukti empiris bahwa partisipasi anggaran mempunyai pengaruh langsung dan signifikan terhadap kinerja manajerial.Berdasarkan pada penjelasan di atas, peneliti mengajukan hipotesis sebagai berikut:

H1a: Partisipasi pada penganggaran berhubungan secara positif terhadap kinerja manajerial.

H1b: Partisipasi pada penganggaran berhubungan secara positif terhadap kinerja anggaran.

2. Partisipasi pada Penganggaran dan Keadilan Persepsian (Perceived Fairness)

Partisipasi penganggaran manajer dan karyawan perusahaan akan meningkatkan kinerja manajerial. Penelitian yang dilakukan oleh Thibaut dan Walker (1975) dalam Wentzel (2002) mengatakan bahwa keadilan persepsian ditentukan oleh proses partisipasi yang dipengaruhi oleh berbagai keputusan yang diambil.Oleh karena itu, ada seseorang tidak setuju dengan hasil suatu keputusan tetapi dapat menerima keputusan tersebut karena proses pengambilan keputusan yang 


\section{Islãmadîna \\ JURNAL PEMIKIRAN ISLAM}

Volume XVIII, No. 2, Juni 2017 : 1-20

dilakukan dengan adil. Dimanaproses yang adil menjadi norma yang diterima umum terhadap perilaku baik dalam konteks sosial maupun dalam konteks proses pengambilan keputusan organisasi.Persepsi individu terhadap keadilan akan meningkat saat seseorang diberikan kesempatan untuk terlibat karena meyakini bahwa keikutsertaan tersebut penting untuk mencapai tujuan yang diharapkan.

Persepsi keadilan dapat dijelaskan melalui dua bentuk, yaitu keadilan prosedural (proceduraljustice) yang dirasakan dalam kebijakan atauprosedur, digunakan dalam membuat keputusan (Folger dan Greenberg : 1983). Teori keadilan prosedural menguji pengaruh prosedur pengambilan suatu keputusan terhadap sikap dan perilaku (Walker, et al., 1974). Thibaut dan Walker (1975) mengemukakan bahwa proses pengambilan keputusan dapat sangat berpengaruh terhadap penerimaan mengenai hasil suatu keputusan. Oleh karena itu, ada kalanya seseorang tidak setuju dengan hasil suatu keputusan tetapi dapat menerima keputusan tersebut karena proses pengambilan keputusan yang dilakukan dengan adil. Dalam hal ini, proses yang adil menjadi norma yang diterima umum terhadap perilaku baik dalam konteks sosial maupun dalam konteks proses pengambilan keputusan organisasi. Dan keadilan distributif (distributive justice) yang menilai keadilan akan hasil sesungguhnya yang didapatkan oleh individu dalam organisasi (Greenberg : 1987).Keadilan distributif merupakan kepercayaan pada individu bahwa suatu hal telah adil saat upah, hukuman, atau sumber daya yang didistribusikan telah sesuai dengan kriteria tertentu (Leventhal, 1976).Keadilan Distribusi (Distributive Justice) diturunkan dari Equity Theory (Adams, 1965). Premise equity theory mengemukakan bahwa seseorang cenderung untuk menilai status sosial mereka dengan penghasilan seperti rewards dan sumberdaya yang mereka terima (Greenberg, 1987). Pandangan lain mengenai keadilan distribusi mengacu pada kewajaran terhadap aktual outcome seperti beban kerja, penghasilan dan lain-lain yang diterima oleh seorang pekerja (Gilliland, 1993; Adams, 1965). Hal ini menunjukkan bahwa respon sikap dan perilaku terhadap penghasilan berkaitan dengan penghasilan yang didasarkan pada persepsi mengenai keadilan (Walster et al., 1978). Pendapat mengenai distributive justice terbentuk ketika suatu kelompok membandingkan penghasilan mereka dengan pihak lain.Wentzel (2002) menunjukkan bahwa partisipasi pada penganggaran berpengaruh pada keadilan distributif dan keadilan prosedural. Berdasarkan berbagai pembahasan di atas, maka peneliti mengajukan hipotesis sebagai berikut:

H2a: Partisipasi pada penganggaran berhubungan secara positif terhadap 
keadilan persepsian distributif.

H2b: Partisipasi pada penganggaran berhubungan secara positif terhadap keadilan persepsian prosedural.

3. Partisipasi pada Penganggaran dan Komitmen terhadap Tujuan (Goal Commitment)

Partisipasi anggaran merupakantingkat pengaruh dan keterlibatan yang dirasakan individu dalam proses perancangan anggaran (Milani 1975). Pada umumnya program anggaran akan lebih berhasil jika melibatkan bawahan atau bawahan ikut bertanggung jawab mengendalikan biaya dan menyusun anggaran untuk area pertanggungjawabannya sendiri, karena partisipasi dari bawahan dalam penyusunan anggaran dapat memberikan kesempatan untuk memasukkan informasi lokal yang lebih baik mengenai area kerja dengan kemampuan khusus yang dimiliki, dan dapat dimasukkan dalam standar atau anggaran yang dipakai sebagai dasar penilaian terhadap kinerja (Merchant 1981).

Melalui komitmen muncul suatu upaya yang sungguh-sungguh dan keterikatan untuk melaksanakan dan mencapai target anggaran yang telah disepakati bersama (Rosidi 2000). Partisipasi dalam penyusunan anggaran menciptakan kesempatan pada bawahan untuk terlibat dan mempengaruhi proses penyusunan anggaran. Dengan keterlibatan bawahan tersebut akan meningkatkan komitmen terhadap sasaran anggaran karena terjadinya proses negosiasi diantara manajer, hal ini tentunya akan mendorong manajer untuk ikut bertangungjawab dalam pencapaian anggaran secara efektif sehingga akan meningkatkan kinerja manajerial.

Terdapat beberapa temuan yang berhubungan dengan goal commitment, yaitu kinerja tugas (task performance) (Donovan dan Radosevich 1998 dalam Li dan Butler 2004), dan akuisisi keterampilan (Seijts dan Latham 2001 dalam Li dan Butler 2004).Chong dan Chong (2002) mengemukakan bahwa saat seseorang memiliki kesempatan untuk terlibat dalam pembuatan keputusan, maka ia akan meningkatkan komitmennya pada tercapainya tujuan organisasi. Nouri dan Parker (1998) membuktikan adanya hubungan positif antara partisipasi pada penganggaran dan komitmen terhadap anggaran. Berdasarkan penjelasan tersebut peneliti mengajukan hipotesis sebagai berikut:

H3: Partisipasi pada penganggaran berhubungan secara positif terhadap komitmen terhadap tujuan.

4. Keadilan Persepsian dan Komitmen terhadap Tujuan

Wentzel (2002) menyatakan bahwa karyawan yang memiliki persepsi saat suatu 


\section{Islãmadìna \\ JURNAL PEMIKIRAN ISLAM}

Volume XVIII, No. 2, Juni 2017 : 1-20

keputusan dibuat dengan proses yang adil, maka komitmennya pada tujuan organisasi akan meningkat karena hasil keputusan yang ada sesuai dengan kepentingan mereka.

Teori instrumental (instrumental theory) yang dibangun oleh Thibaut dan Walker (1975) dalam Lau dan Moser (2008) menyatakan bahwa seseorang lebih banyak memperhatikan pada penerimaan hasil sesuai yang diharapkan, mereka menyukai prosedur yang adil karena akan membuahkan hasil yang adil (Lau dan Moser 2008). Adanya perasaan diperlakukan adil dapat memberikan beberapa dampak positif, di antaranya berupa loyalitas, komitmen, dan kinerja yang bagus dari karyawan (Lau dan Moser 2008).Keadilan sistem evaluasi menjadi penentu perilaku karyawan yang diharapkan dapat meningkatkan komitmen dan kinerja (Lind dan Tyler 1988; Lau dan Lim 2002 dalam Lau et al. 2008) dalam Hasnisari (2014). Oleh karena itu, peneliti mengajukan hipotesis sebagai berikut:

H4a: Keadilan distributif berhubungan secara positif terhadap komitmen terhadap tujuan.

H4b:Keadilan prosedural berhubungan secara positif terhadap komitmen terhadap tujuan.

5. Komitmen terhadap Tujuan dan Kinerja

Perusahaan harus menetapkan tujuan sebagai petunjuk semua stakeholder dalam menjalankan roda bisnis. Dengan tercapainya tujuan menunjukkan organisasi telah berjalan dengan baik, oleh karena itu memiliki kinerja yang baik. Untuk mencapai tujuan yang sudah ditetapkanmembutuhkan komitmen semua pihak untuk mencapainya. Maka kominten untuk mencapai tujuan sangat penting dimiliki oleh semua pihak dalam perusahaan.Oleh karena itu, Affective goalcommitment merupakan kemauan seseoranguntuk melakukan usaha yang besar untuk kepentingan organisasi.Oleh karena itu, komitmen terhadap tujuan berpengaruh positif terhadap kinerja (Lau dan Moser 2008).Maka kami mengajukan hipotesis sebagai berikut:

H5a: Komitmen terhadap tujuan berhubungan positif terhadap kinerja manajerial.

H5b: Komitmen terhadap tujuan berhubungan positif terhadap kinerja anggaran.

\section{METODE PENELITIAN}

1. Objek Penelitian dan Sampel

Penelitian ini dilakukan pada Lembaga Keuangan Mikro Syariah yaitu Baitul 
mal Wattamwil (BMT) di Kabupaten Banyumas.Sampel yang diambil sebagai data adalah anggota institusi yang pernah ikut dalam proses penyusunan anggaran, sehingga mereka memahami pertanyaan yang diajukan.

Proses penganggaran pada tiap-tiap BMT biasanya dilakukan oleh dewan pengurus dan manajemen. Meskipun disetiap BMT berbeda dalam proses penganggaran, secara umum levelmanajer akan terlibat dalam proses penyusunan anggaran.

\section{Instrumen Pengukuran}

Penelitian ini merupakan replikasi dari studi terdahulu yang telah dilakukan oleh Wentzel (2002) dan Hasniasari (2014), sehingga pengukuran pada variabelnya menggunakan instrumen yang telah dipakai oleh penelitian tersebut.Pendekatan ini memungkinkan untuk membandingkan hasil ini dengan penelitian Wentel (2002).Instrumen yang digunakan oleh Wentzel (2002) menggunakan tujuh poin skala Likert yang merupakan skala yang didesain untuk menentukan seberapa kuat subjek menyetujui atau tidak menyetujui suatu pernyataan yang ada di dalam kuesioner. Adapun penjelasan kuesioner yang dipakai adalah sebagai berikut.

\section{Partisipasi pada Penganggaran}

Variabel ini diukur dengan menggunakan butir pengukur yang dibuat oleh Milani (1975) dalam Wentzel (2002). Responden ditanya tentang tingkat keikutsertaan mereka pada proses penganggaran. Instrumen ini cukup populer dan kredibel dalam penelitian mengenai partisipasi peng-anggaran terbukti dengan telah digunakannya skala Milani (1975) pada studi yang dilakukan oleh Linquist (1995), Nouri dan Parker (1998), dan Sholihin et al. (2011) dalam Hasniasari (2014).

\section{Keadilan Persepsian}

Dua bentuk keadilan persepsian diukur pada penelitian ini, yaitu keadilan prosedural dan keadilan distributif. Keadilan prosedural diukur dengan menggunakan empat butir instrumen yang dibuat Magner dan Johnson (1995) dalam Wentzel (2002) yang mengacu pada lima aturan keadilan yang dijabarkan oleh Leventhal (1980); mencakup konsistensi antar perseorangan dan waktu, akurasi, etika, dan pengurangan bias. Keadilan distributif diukur menggunakan lima butir yang dikembangkan Magner dan Johnson (1995). Skala ini dibuat untuk digunakan dalam pengukuran beberapa dasar komparatif pada lingkungan penganggaran, yaitu kebutuhan, ekspektasi, dan kepantasan (Hasniasari,2014). 


\section{Islãmadîna \\ JURNAL PEMIKIRAN ISLAM}

Volume XVIII, No. 2, Juni 2017 : 1-20

5. Komitmen terhadap Tujuan Anggaran

Tiga butir pengukuran yang dikembangkan oleh Latham dan Steele (1983) digunakan untuk mengukur variabel ini.Instrumen ini mengukur bagaimana individu berkomitmen pada tujuan tertentu dan perjuangan mereka untuk mencapainya (Wentzel 2002). Aplikasi pengukuran ini juga telah digunakan oleh Wentzel (2002) dalam penelitian sejenis.

6. Kinerja

Pada penelitian ini dilakukan pengukuran dua tipe kinerja, yaitu kinerja manajerial dan kinerja penganggaran sebagaimana yang telah dilakukan oleh Wentzel (2002). Kinerja manajerial diukur menggunakan instrumen Mahoney et al. (1963) yang menanyakan responden tentang kinerja mereka dalam delapan dimensi, yaitu: perencanaan, investigasi, koordinasi, evaluasi, supervisi, staffing, negosiasi, dan mewakili. Kinerja penganggaran diukur dengan meminta responden untuk memberikan penilaian pada kinerja penganggaran di organisasi yang diteliti sebagaimana yang telah dilakukan Wentzel (2002) dalam Hasnisari (2014).

\section{Metode Analisis}

Alat analisis yang digunakan dalam penelitian ini adalah partial least square (PLS) yang merupakan teknik statistika multivariat yang melakukan perbandingan antara variabel dependen berganda dan variabel independen berganda. Hal yang menjadi alasan pemilihan metoda tersebut dalam penelitian ini adalah: (1) penggunaan OLS (ordinary least square) tidak tepat untuk menganalisis model dengan lebih dari satu variabel dependen dikarenakan alasan multikolineritas;(2) PLS merupakan SEM berbasis varian yang dapat memprediksi model untuk mengembangkan teori, (3) hasil yang akan didapatkan dari olah data menggunakan PLS tetap kokoh meskipun terdapat data yang tidak normal atau hilang, (4) dapat digunakan pada sampel kecil, (5) dapat digunakan pada data dengan berbagai tipe skala (Hartono dan Abdillah 2009) dalam Hasnisari (2014).

\section{Model Pengukuran}

Model pengukuran atau outer model dievaluasi dengan memeriksa validitas dan reliabilitas pada konstruk. Validitas dievaluasi dengan memeriksa validitas konvergen dan diskriminan dari masing-masing indikator.

Validitas konvergen diukur dengan melihat outer loadings dan average variance extracted(AVE). Jika nilai outer loadings kurang dari 0,7 , indikator ini dapat dihapus dari konstruknya karena indikator ini tidak termuat (load) ke 
konstruk yang mewakilinya. Indikator juga bisa dikatakan valid jika memiliki nilai AVE lebih dari 0,5 yang artinya probabilitas indikator tersebut konvergen dan masuk pada konstruk yang dimaksud lebih besar, yaitu 0,5 (Gazali, 2011). Uji validitas diskriminan dapat dilakukan dengan melihat nilai crossloading. Validitas diskriminan yang baik dapatdilihat dari nilai cross loading pada indikator pada variabel laten di dalam model, perbedaan yang signifikan antar indikator pada variabel latennya dibanding variabel lain dalam konstruk akan menguatkan asumsi validitas diskriminan. Reliabilitas model akan diukur dengan melihat CronbachsAlpha dan composite reliability.

\section{Model Struktural}

Evaluasi model struktural dilakukan untuk memprediksi hubungan kausal antarvariabel atau pengujian hipotesis (Gazali, 2015). Model struktural atau inner model dengan PLS dievaluasi dengan memeriksa persentase varian yang dijelaskan dengan nilai $R$-square dari variabel independen laten. Stabilitas pada estimasi dapat dievaluasi dengan menggunakan t-test melalui proses bootstrapping.

Analisis model struktural dilakukan untuk melihat korelasi antara hipotesis. Sebelum me-lakukan analisis model struktural tersebut, peneliti melakukan pengujian bivariate correlation dan multivariate correlation di dalam model.

Model penelitian disajikan dalam Gambar 1.

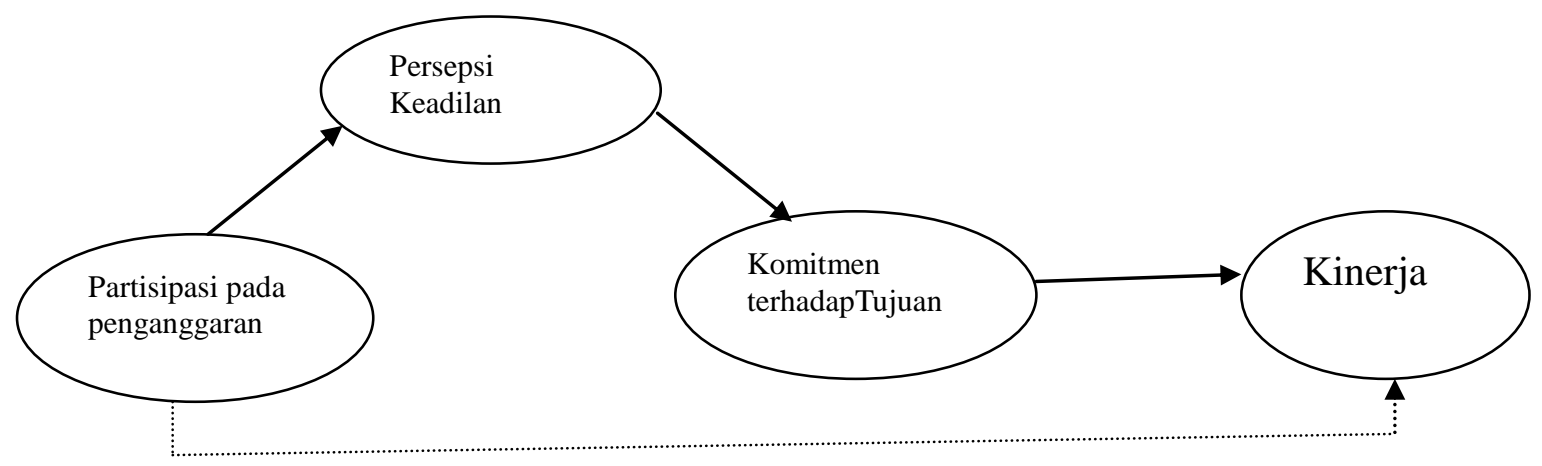

Gambar 1. Model Penelitian

\section{Hasil Penelitian}

Penelitian ini dilakukan pada Lembaga Keuangan Mikro syariah atau Baitul Mal Wattamwil (BMT), Baituttamwil Muhammadiyah (BTM) dan lembaga keuangan mikro syariah yang lain di Kabupaten Banyumas. Dengan menggunakan kuesioner diperoleh hasil 40 kuesioner yang digunakan dalam penelitian ini. 


\section{Islãmadîna \\ JURNAL PEMIKIRAN ISLAM}

Volume XVIII, No. 2, Juni 2017 : 1-20

\section{Analisis Model Pengukuran}

Sebelum dilakukan pengujian terhadap hipotesis yang sudah disusun, dilakukan pengujian terhadap validitas dan reabilitas data. Tujuan dari pengujian ini adalah untuk menyatakan bahwa uji validitas digunakan untuk mengukur sah, atau valid tidaknya suatu kuesioner. Suatu kuesioner dikatakan valid jika pertanyaan pada kuesioner mampu untuk mengungkapkan sesuatu yang akan diukur oleh kuesioner tersebut(Ghozali, 2015). Suatu tes dapat dikatakan memiliki validitas yang tinggi jika tes tersebut menjalankan fungsi ukurnya, atau memberikan hasil ukur yang tepat dan akurat sesuai dengan maksud dikenakannya tes tersebut. Suatu tes menghasilkan data yang tidak relevan dengan tujuan diadakannya pengukuran dikatakan sebagai tes yang memiliki validitas rendah.

Sedangkan reabilitas adalah menyatakan bahwa reliabilitas adalah alat untuk mengukur suatu kuesioner yang merupakan indikator dari peubah atau konstruk. Suatu kuesioner dikatakan reliabel atau handal jika jawaban seseorang terhadap pernyataan adalah konsisten atau stabil dari waktu ke waktu. Reliabilitas suatu test merujuk pada derajat stabilitas, konsistensi, daya prediksi, dan akurasi. Pengukuran yang memiliki reliabilitas yang tinggi adalah pengukuran yang dapat menghasilkan data yang reliabel (Ghozali, 2015).

Tabel1Combined loadings and cross-loadings

PP KMKD KP GC Type (a SE P value

$\begin{array}{lllllllllll}\text { PP1 0.881 } & -0.080 & -0.211 & 0.193 & -0.091 & \text { Reflect } & 0.108 & <0.001 \\ \text { PP2 0.874 } & 0.075 & 0.078 & -0.415 & 0.049 & \text { Reflect } & 0.109 & <0.001 \\ \text { PP3 0.937 } & 0.090 & -0.060 & 0.157 & -0.016 & \text { Reflect } & 0.106 & <0.001 \\ \text { PP4 0.919 } & 0.007 & 0.024 & 0.009 & 0.037 & \text { Reflect } & 0.107 & <0.001 \\ \text { PP5 0.917 } & -0.094 & 0.166 & 0.042 & 0.020 & \text { Reflect } & 0.107 & <0.001 \\ \text { KM1 } & 0.114 & 0.849 & -0.180 & -0.333 & 0.177 & \text { Reflect } & 0.110 & <0.001 \\ \text { KM2 } & -0.182 & 0.797 & 0.061 & -0.708 & 0.492 & \text { Reflect } & 0.112 & <0.001 \\ \text { KM3 } & -0.355 & 0.750 & 0.313 & 0.296 & -0.291 & \text { Reflect } & 0.115 & <0.001 \\ \text { KM4 } & 0.077 & 0.887 & -0.021 & 0.074 & -0.118 & \text { Reflect } & 0.108 & <0.001 \\ \text { KM5 } & -0.003 & 0.770 & -0.117 & 0.472 & -0.037 & \text { Reflect } & 0.114 & <0.001 \\ \text { KM6 } & 0.064 & 0.897 & 0.053 & -0.198 & 0.279 & \text { Reflect } & 0.108 & <0.001 \\ \text { KM7 } & -0.023 & 0.716 & 0.138 & 0.018 & -0.320 & \text { Reflect } & 0.116 & <0.001 \\ \text { KM8 } & 0.237 & 0.874 & -0.193 & 0.414 & -0.242 & \text { Reflect } & 0.109 & <0.001\end{array}$




\begin{tabular}{lllllllll}
\hline KD1 & 0.612 & 0.037 & 0.771 & -0.370 & 0.062 & Reflect & 0.114 & $<0.001$ \\
KD2 & 0.204 & -0.366 & 0.924 & 0.227 & -0.125 & Reflect & 0.106 & $<0.001$ \\
KD3 & 0.109 & -0.216 & 0.909 & 0.195 & -0.166 & Reflect & 0.107 & $<0.001$ \\
KD4 & -0.364 & 0.374 & 0.791 & -0.002 & -0.244 & Reflect & 0.113 & $<0.001$ \\
KD5 & -0.699 & 0.312 & 0.675 & -0.147 & 0.610 & Reflect & 0.118 & $<0.001$ \\
KP1 & -0.057 & -0.183 & 0.005 & 0.839 & -0.363 & Reflect & 0.110 & $<0.001$ \\
KP2 & -0.247 & -0.071 & -0.054 & 0.833 & -0.307 & Reflect & 0.111 & $<0.001$ \\
KP3 & -0.437 & 0.204 & 0.232 & 0.800 & 0.431 & Reflect & 0.112 & $<0.001$ \\
KP4 & 0.006 & 0.211 & 0.060 & 0.805 & 0.163 & Reflect & 0.112 & $<0.001$ \\
KP5 & 0.371 & -0.193 & -0.190 & 0.850 & -0.146 & Reflect & 0.110 & $<0.001$ \\
KP6 & 0.203 & 0.091 & 0.166 & 0.654 & 0.277 & Reflect & 0.119 & $<0.001$ \\
KP7 & 0.006 & -0.063 & -0.037 & 0.841 & 0.165 & Reflect & 0.110 & $<0.001$ \\
KP8 & 0.175 & 0.046 & -0.131 & 0.830 & -0.134 & Reflect & 0.111 & $<0.001$ \\
GC1 & 0.010 & -0.062 & -0.068 & -0.062 & 0.927 & Reflect & 0.106 & $<0.001$ \\
GC2 & 0.200 & -0.073 & 0.107 & -0.113 & 0.915 & Reflect & 0.107 & $<0.001$ \\
GC3 & -0.214 & 0.139 & -0.039 & 0.180 & 0.898 & Reflect & 0.107 & $<0.001$
\end{tabular}

Notes: Loadings are unrotated and cross-loadings are oblique-rotated. SEs and $\mathrm{P}$ values are for loadings. $\mathrm{P}$ values $<0.05$ are desirable for reflective indicators.

\section{Tabel 2 Koefisien Variabel Laten}

\begin{tabular}{|c|c|c|c|c|c|c|}
\hline & $\mathrm{pp}$ & KM & KD & $\mathrm{KP}$ & GC & \\
\hline R-squared & & 0.650 & 0.606 & 0.471 & 0.650 & \\
\hline Adj. R-squared & & 0.631 & 0.595 & 0.457 & 0.631 & \\
\hline Composite reliab. & 0.958 & 0.942 & 0.910 & 0.938 & 0.938 & \\
\hline Cronbach's alpha & 0.945 & 0.929 & 0.873 & 0.923 & 0.901 & \\
\hline Avg. var, extrac. & 0.820 & 0.673 & 0.671 & 0.654 & 0.834 & \\
\hline Full collin. VIF & 2.202 & 3.123 & 2.653 & 3.534 & 2.288 & \\
\hline Q-squared & & 0.660 & 0.596 & 0.477 & 0.640 & \\
\hline Min & -2.676 & -3.866 & -3.701 & -2.339 & -3.890 & \\
\hline Max & 1.584 & 1.232 & 1.809 & 1.250 & 1.905 & \\
\hline Median & 0.244 & 0.294 & 0.131 & 0.308 & 0.457 & \\
\hline Mode & 0.732 & 0.826 & 1.115 & 1.063 & 0.457 & \\
\hline Skewness & -0.726 & -1.581 & -1.320 & -0.812 & -1.492 & \\
\hline Exc. kurtosis & 0.156 & 3.644 & 3.041 & -0.347 & 4.092 & \\
\hline Unimodal-RS & Yes & Yes & Yes & Yes & Yes & \\
\hline Unimodal-KMV & Yes & Yes & Yes & Yes & Yes & \\
\hline Normal-JB & Yes & No & No & Yes & No & \\
\hline Normal-RJB & No & No & No & Yes & No & \\
\hline Histogram & View & View & View & View & View & \\
\hline
\end{tabular}




\section{Islãmadîna \\ JURNAL PEMIKIRAN ISLAM}

Validitas konvergen diukur dengan melihat outer loadings dan average variance extracted (AVE). Terdapat dua kriteria untuk menilai apakah outer loadings memenuhi syarat validitas konvergen untuk konstruk reflektif yaitu (1) loading harus di atas 0,70 dan (2) nilai p signifikan $(<0,05)$ (hair, dkk, 2013 dalam ratmono, 2014). Dari data gambar 4.1 diatas terlihat bahwa rata loadingnya diatas 0,70 sehingga memenuhi syarat validitas konvergen. Sedangkan AVE lebih dari 0,5 yang artinya probabilitas indikator tersebut konvergen dan masuk pada konstruk. Dari gambar 4.2 rata-rata nilai AVE diatas 0,5. Dari kedua indikator tersebut maka model memnuhi syarat valididtas konvergen. Sedangkan reabilitas diukur dengan menggunakan cronbachs alpha dan composite realibility. Dari gambar 4.2 terlihat bahwa nilai cronhachs alpha dan composite realibity diatas 0,8 . Dengan demikian instrumen ini memenuhi syarat realibilitas, yang artinya semua indikator akurat, konsisten dan presisi yang signifikan pada instrumen dalam mengukur variabel.

\section{Analisis Model Struktural}

Setelah melihat masing-masing hubungan antar variabel, peneliti melakukan analisis terhadap hubungan antar variabel di dalam model. Untuk meneliti pengaruh partisipasi pada penganggaran terhadap kinerja (manajerial dan Anggaran), dibangun dua model seperti pada gambar dibawah.

Berdasarkan gambar 2 dan gambar 3 peneliti melakukan analisis terhadap masing-masing model secara terpisah. Hasil pengolahan data dengan menggunakan warpPLS pada model tersebut seperti pada gambar dibawah.

\section{Gambar 1. Penganggaran Terhadap Kinerja Manajerial}

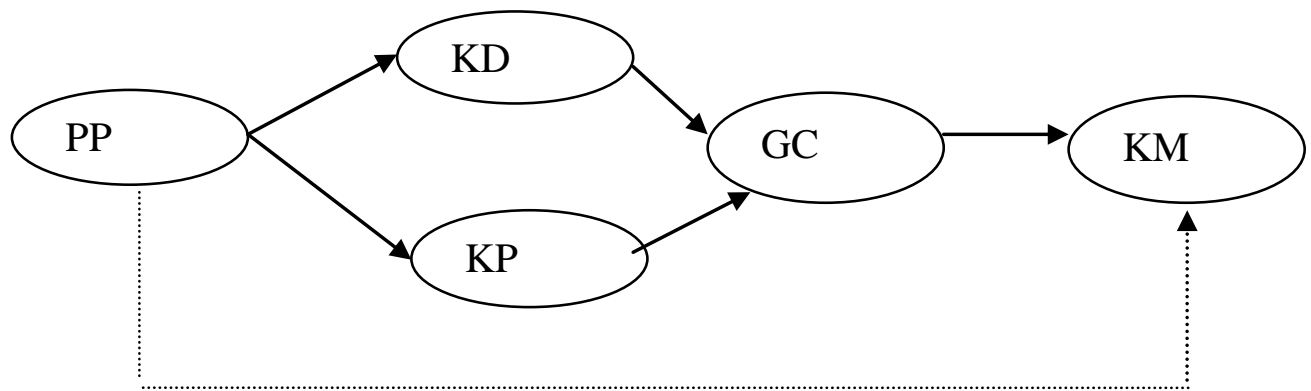

Keterangan : PP Partisipasi Penganggaran; KD Keadilan Distributif; KP Keadilan Persepsian; GC Goal Commitment; KM Kinerja Manajerial.

\section{Gambar 2 Penganggaran Terhadap Kinerja Anggaran}




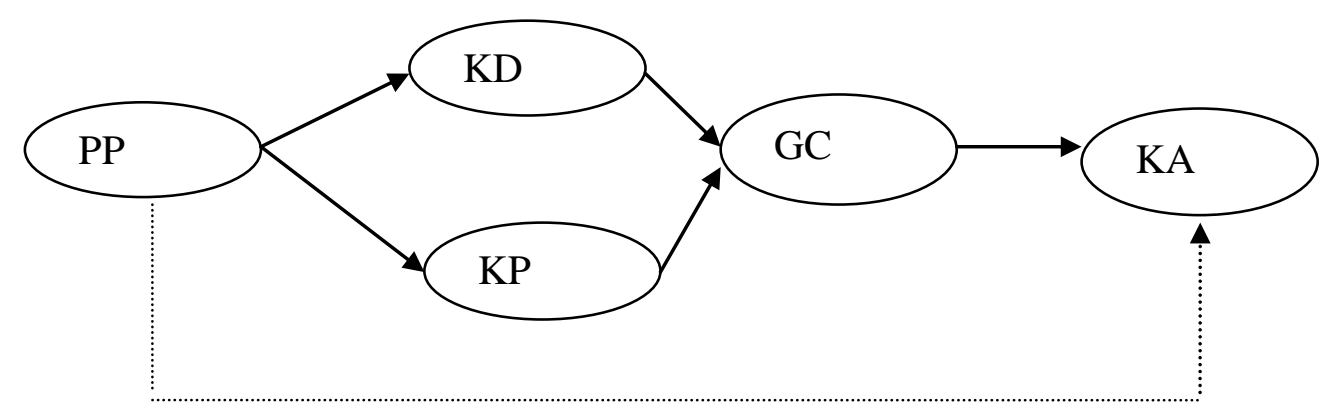

Keterangan : PP Partisipasi Penganggaran; KD Keadilan Distributif; KP

Keadilan Persepsian; GC Goal Commitment; KM Kinerja Anggaran.

Tabel 2 Hasil PLS untuk model 1

Dari/ke

Partisipasi Penganggaran

Keadilan Prosedural

Keadilan Distributif

Komitmen thd Tujuan

Rsquare

Level signifikansi $\mathrm{p}<0,01$
Keadilan

0,69

Keadilan

Distributif

0,78

Komitmen

thd Tujuan

0,37

0,56

0,29

0,471

$$
0,606
$$

0,65

0,48

0,65

Tabel 2 Hasil untuk Model PLS 2

Dari/ke

Partisipasi Penganggaran

Keadilan Prosedural

Keadilan Distributif

Komitmen thd Tujuan

Rsquare

Level signifikansi $\mathrm{p}<0,01$

$\begin{array}{llll}\begin{array}{lll}\text { Keadilan } \\ \text { Prosedural }\end{array} & \begin{array}{l}\text { Keadilan } \\ \text { Distributif }\end{array} & \begin{array}{l}\text { Komitmen } \\ \text { thd Tujuan }\end{array} & \begin{array}{l}\text { Kinerja } \\ \text { Anggaran } \\ \end{array} \\ & 0,78 & & 0,60 \\ & & 0,55 & \\ & & 0,29 & \\ 0,47 & 0,61 & 0,65 & 0,30\end{array}$

\section{Hasil Uji Hipotesis}

1. Hipotesis 1a : Partisipasi Penganggaran berpengaruh langsung dan posisitif terhadap kinerja manajerial. Dan Hipotesis $1 \mathrm{~b}$ : partisipasi penganggaran berpengaruh alngsung dan posisitif terhadap kinerja Anggaran.

Dari data statistik menunjukkan bahwa nilai koefisien 0,43 dan signifikan pada level 0,01. Oleh karena itu dapat disimpulkan bahwa partisipasi penganggaran berpengaruh positif terhadap kinerja manajerial. Sedangkan pada tabel 4.2 koefisien sebesar 0,60 dan signifikan pada level 0,01. Dapat 


\section{Islãmadîna

disimpulkan bahwa partisipasi penganggaran juga berpengaruh positif terhadap kinerja anggaran. Oleh karena itu baik hipotesis 1a dan 1b bahwa partisipasi penganggaran berpengaruh positif dan langsung terhadap kinerja manajerial dan kinerja anggaran diterima.

2. Hipotesis 2a Partisipasi penganggaran berpengaruh positif terhadap Keadilan distributif.

Hipotesis 2b Partisipasi penganggaran berpengaruh positif terhadap keadilan prosedural.

Dari tabel 4.1 menunjukkan nilai koefisien keadilan prosedural sebesar 0,69 dan sgnifikan pada level 0,001. Hal ini menunjukkan bahwa partisipasi penganggaran berpengaruh positif terhadap keadilan prosedural didukung. Sedangkan pengaruh partisipasi penganggran terhadap keadilan distributif nilai koefisien sebesar 0,78 dan signifikan pada level 0,01 diterima. Oleh karena itu partisipasi penganggaran berpengaruh langsung dan positif terhadap keadilan distributif.

3. Hipotesis 3 Partisipasi Penganggaran berpengaruh positif terhadap komitmen terhadap tujuan (Goal Commitment). Dati tabel 4.1 menunjukkan bahwa hipotesis partisipasi penganggaran berpengaruh positif terhadap komitmen terhadap tujuan diterima.

4. Hipotesis 4akeadilan Distributif berpengaruh positif terhadap komitmen terhadap Tujuan (GC).Hipotesis 4b keadilan Prosedural berpengaruh positif terhadap komitmen terhadap Tujuan (GC). Dari data tabel 4.1 diatas nilai koefien hanya sebesar 0,29 dengan $\mathrm{p}>0,01$. Sehingga hipotesis 4 a ditolak, dengan kata lain keadilan ditributif tidak berpengaruh terhadap komitmen terhadap tujuan (GC). Sedangkan keadilan prosedural berpengaruh positif terhadap komitmen terhadap tujuan (GC), sehingga hipotesis $4 \mathrm{~b}$ diterima.

\section{Kesimpulan}

Secara keseluruhan dapat dikatakan bahwa keadilan Prosedural dan komitmen terhadap tujuan memdiasi hubungan antara partisipasi pada penganggaran dan kinerja (baik manajerial maupun anggaran). Penelitian ini bertujuan untuk mengetahui apakah partisipasi pada penganggaran mempengaruhi kinerja melalui keadilan persepsian dan komitmen untuk mencapai tujuan anggaran, dengan mereplikasi penelitian yang dilakukan oleh Wintzel (2002), dan Hasniasari (2014), tetapi dengan objek penelitian berbeda. Penelitian ini dilakukan pada lembaga keuangan syariah/BMT yang ada di Banyumas. Secara spesifik penelitian ini ingin mengetahui apakah partisipasi penganggaran 
mempengaruhi kinerja dan apakah keadilan persepsian dan komitmen pada tujuan memediaasi hubungan partisipasi pada penganggaran kinerja.

Temuan pada penelitian ini adalah bahwa partisipasi penganggaran berpengaruh positif terhadap kinerja manajerial, sama dengan hasil kedua penelitian sebelumnya. Partisipasi penganggaran juga berpengaruh positif terhadap keadilan prosedural dan keadilan distributif. Begitu juga dengan partisipasi penganggaran berpengaruh terhadap komitmen terhadap tujuan.

Secara keseluruhan, penelitian ini mendukung kedua penelitian sebelumnya. Hal ini dapat disimpulkan bahwa keikutsertaan karyawan dalam proses penentuan keputusan organisasi sangat mempengaruhi mereka secara emosional untuk mencapai tujuan yang telah ditetapkan. Penelitian ini membuktikan bahwa hubungan antara komitmen terhadap tujuan anggaran dan kinerja adalah positif. Temuan lain adalah partisipasi penganggaran berpengaruh positif terhadap kinerja manajerial dan anggaran. Oleh karena itu dapat disimpulkan dari penelitian ini adalah bentuk keadilan persepsian yang memediasai partisipasi penganggaran dan komitmen mencapai tujuan adalah keadilan prosedural. 


\section{DAFTAR PUSTAKA}

Alutto, J. A., dan Belasco, J. A. 1972. A typology for participation in organizational decision making.Admistrative Science Quarterl.

Aji, G.,dan Kholili, 2014. Pengaruh Partisipasi Anggaran Terhadap Kinerja Manajerial Melalui Kemampuan Interpersonal Pemimpin Berbasis Syariah (Studi Kasus Pada Bmt Di Kota Pekalongan. Jurnal Hukum Islam.

Baiman, S., dan Evans, J. H. 1983. Predecision information and participative management control systems. Journal of Accounting Research, 21(Autumn).

Baron, R. M. dan Kenny, D. A. 1986. The moderator-mediator variable distinction in social psychological research: conceptual, strategic, and statistical considerations. Journal of Personality and Social Psychology.

Becker, S. dan Green, D. 1960. Budgeting and employee behavior. Journal of Business, (October).

Brownell, P. (1982). The role of accounting data in performance evaluation, budgetary participation, and organization effectiveness.Journalof Accounting Research, (Spring).

Chong, V.K. dan K.M. Chong. 2002. "Budget Goal Commitment and Informational Effects of Budget Participation on Performance: A Structural Equation Modeling Approach". Behavioral ResearchIn Accounting. Vol. 14.

Ghozali, I. 2011. Structural Equation Modeling:Metode alternatif dengan Partial Least Square edisi 3. Badan Penerbit Universitas Diponegoro: Semarang.

Ghozali, I. 2015. Partial Least Squares, Konsep, Teknik dan Aplikasi menggunakan SMART PLS 3.0edisi 2. Badan Penerbit Universitas Diponegoro: Semarang.

Ghozali, I.,Aprilia, K. 2013. Teknik Penyusunan Skala Likert. Penerbit Fatwa Publishing. Semarang.

Jermias, J..dan Setiawan, T. 2007. The moderating effects of hierarchy and control systems on the relationship between budgetary participation and performance. Management Accounting Research.

Hartono, J. 2008. Pedoman survei kuesioner:Mengembangkan kuesioner, mengatasi bias, dan meningkatkan respon. Badan PenerbitFakultas Ekonomika dan Bisnis UGM. 
Hasniasari, Sholihin. 2014. Analisis Hubungan Penganggaran Partisipatif dan Kinerja: Pengujian Efek Mediasi Keadilan Persepsian dan Komitmen pada Lembaga Hukum Sektor Publik di Indonesia. Jurnal Akuntansi dan Keuangan, Vol. 16, No. 1, Mei 2014.

Kim, W. C., dan Maugborne, R. A. 1993. Procedural justice, attitudes, and subsidiaries top management compliance with multinationals' corporate strategic decisions. Academy ofManagement Journal.

Korsgaard, M.A., Schweiger, D.M., dan Sapienza, H.J. 1995. Building commitment, attachment, and trust in strategic decision making teams: The role of procedural justice. Academyof Management Journa.

Latham, G. P., dan Steele, T. P. 1983. The motivational effects of participation versus goal setting in performance.Academy of Manage-ment.

Lau, C. M., dan Moser, A. 2008. Behavioral effects on nonfinancial measures: The role of procedural fairness. Behavioral Research inAccounting.

Leventhal, G. P. 1976. What should be done withequity theory? New approaches to the study of fairness in social relationship.

Li, A., dan Butler, A. B. 2004. The effects of participation in goal setting and goal rationales on goal commitment: An exploration of justice mediators. Journal of Business and Psychology.

Libby, T. 1999. The influence of voice and explanation on performance in a participative budgeting setting.Accounting, Organization, and Society.

Linquist, T. M. 1995. Fairness as antecedents to participative budgeting: examining the effects of distributive justice, procedural justice and referent cognitions on satisfaction and per-formance. Journal of Management AccountingResearch.

Locke, E. A. (1968). Toward a theory of task motivation and incentives.Organizational Behavior and Human Performance.

Locke, E. A., Lantham, G. P., dan Erez, M. 1988. The determinants of goal commitment. Academy of Management Review.

Mulyasari,W., dan Sugiri, S. 2005. Keadilan, Komitmen pada Tujuan dan Job Relevant Information dalam Penganggaran Partisipatif. Jurnal Riset Akuntansi Indonesia, Vol. 8 No.3.

McFarlin, D. B., dan Sweeney, P. D. 1992. Distributive justice and procedural justice as predictors of satisfaction with personal and organizational outcomes.Academy of Management Journal.

Nouri, H., dan Parker, R.J. 1998. The relationship between budget participation and job perfor-mance: The roles of budget adequacy and organizational commitment. Accounting, Organizational, and Society. 


\section{Islãmadîna \\ JURNAL PEMIKIRAN ISLAM}

Volume XVIII, No. 2, Juni 2017 : 1-20

Ratmono, D., dan Sholihin. 2013. Analisis SEM PLS dengan WarpPLS 3.0. penerbit Andi Yogyakarta

Rosidi. 2000. "Partisipasi dalam Penganggaran dan Prestasi Manajer: Pengaruh Komitmen Organisasi dan Informasi Job Relevant”. Jurnal Ekonomi danManajemen, Vol.1, No.1.

Sekaran, U. 2010. Research methods for business:A skill building approach. New Jersey, NJ: John Willey and Sons.

Sholihin, M., dan Pike, R. 2009. Fairness in performance evaluation and its behavioral consequences.Accounting and Business Research.

Sholihin, M., Pike, R., Mangena, M., dan Li, J. 2011. Goalsetting participation and goal commitment: Examining the mediating roles of procedural fairness and interpersonal yrust in UK financial services organization. TheBritish Accounting Review.

Trushman, M. L., dan Naddler, D. A. 1978. Information processing as an integrating concept in organizational design.Academy of Mana-gement Review, 3(July).

Wentzel, K. 2002. The influence of fairness perceptions and goal commitment to managers' performance in budget setting.BehavioralResearch in Accounting, 14. 